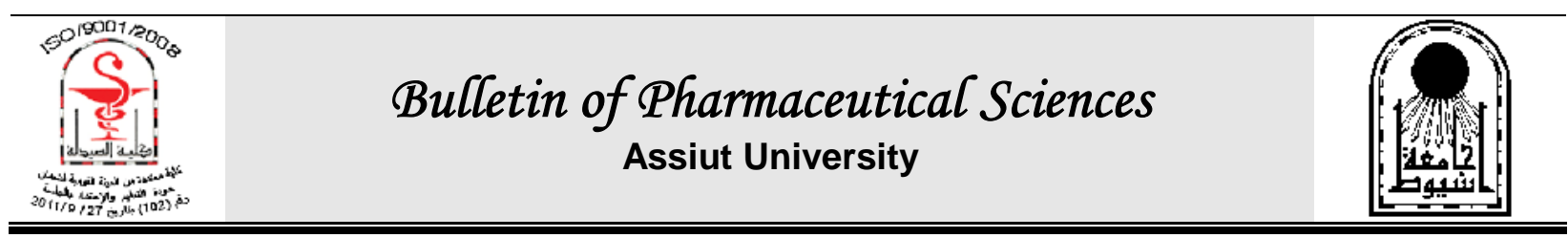

\title{
EFFECT OF STORAGE CONDITIONS ON THE STABILITY OF ALBENDAZOLE AND OXYTETRACYCLINE VETERINARY PRODUCTS MARKETED IN SUDAN
}

\author{
Yagoub M. M. Yagoub ${ }^{1}$, Siham Abdoun ${ }^{2}$ and Hisham I. Seri ${ }^{3 *}$ \\ ${ }^{1}$ Department of Veterinary Medicine, Gingko Investment Co, LTD-Sudan \\ ${ }^{2}$ National Drug Quality Control Laboratory, National Medicine and Poisons Board, Sudan \\ ${ }^{3}$ Department of Veterinary Medicine and Surgery, College of Veterinary Medicine, Sudan \\ University of Science and Technology
}

The effect of storage conditions on the stability of albendazole and oxytetracycline veterinary products marketed in Sudan was evaluated.

Stability of Albendazole suspension and Oxytetracycline injectable solution has been investigated under two different storage conditions, according to the ICH guidelines for the drug stability testing.

The change in colour (using visual inspection), $p H$ value (using $\mathrm{pH}$ meter) and the degradation process by an HPLC method, was monitored at different time points. Investigated drugs were stored in two different stores. The first one $(A)$ is equipped with controlled temperature and humidity control systems. The second one (B) was a veterinary pharmacy selected randomly from East Nile locality. The temperature and humidity in the stores $A$ and $B$ were monitored and recorded daily using hygrometer for I year.

At the beginning of the study all products were proved to be compatible with the recommendations of the manufacturers. There was no change in the colour of albendazole during the nine months at both stores. The $\mathrm{pH}$ values in the first store expressed noticeable reduction, although it is still within the recommended range. Following nine months storage the drug content of albendazole was reduced below the recommended level. In the second store (B), there was no change in the colour of both albendazole products tested. There was considerable change in $\mathrm{pH}$ value during the nine months storage, but still it is within the recommended level. The active pharmaceutical ingredient concentration (assay \%), of albendazole fell below the recommended level (USP) following storage for nine months.

In the first store (A), the two oxytetracycline products expressed no change in colour and there was slight reduction in $\mathrm{pH}$ level (but still within the recommended level) within the six months storage period. The experiment was terminated just after six months due to the reduction of the active ingredient concentration (assay \%) below the recommended level. In the second store $(B)$, there is only change in the colour in one of the products following six months storage. $\mathrm{pH}$ level also here expressed moderate reduction, but still in the recommended range. The concentration (assay \%), of oxytetracycline expressed prominent reduction following storage for six months.

The obtained results are of interest for stability studies and/or quality control purposes of Albendazole and Oxytetracycline commercial products. Here we could conclude that, the two veterinary drugs evaluated in this study (albendazole and oxytetracycline) proved to be unstable under environmental conditions in veterinary pharmacies in Khartoum state, Sudan. 


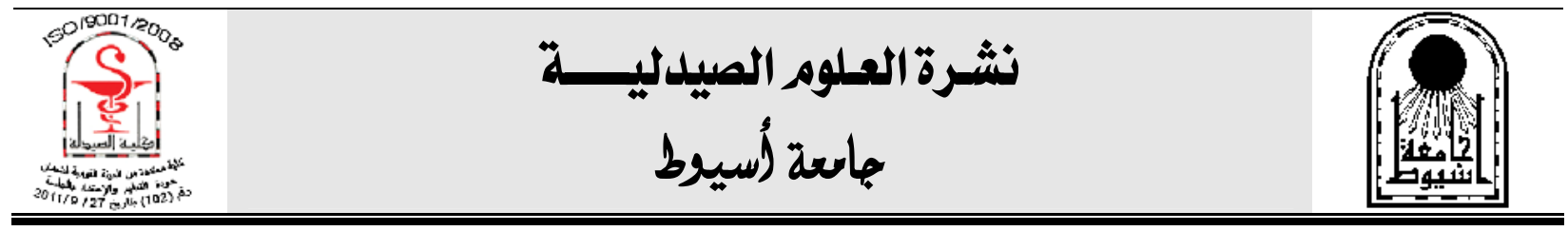

\section{آثر ظروف التخزين علي ثبات آثنين من الادوية البيطرية المسوقة في السودان: البندازول و أوكسي تثر اسايكلين}

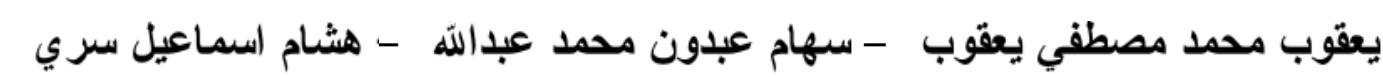

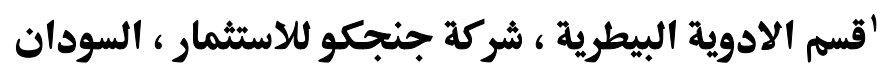

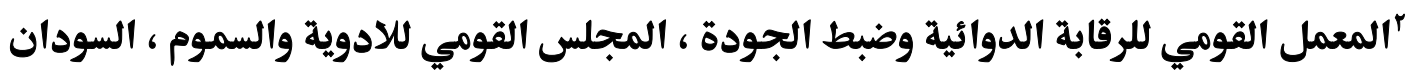
"قسم طب و جراحة الحيوان ، كلية الطب البيطري ، جامعة السودان للعلوم والتكنولوجيا

تم فحص ثبات الالبندازول (معلق) و الاوكسي ثتز اسايكلين (محلول للحقن) تحت ظــلـ ظـــروف مختلفـــة

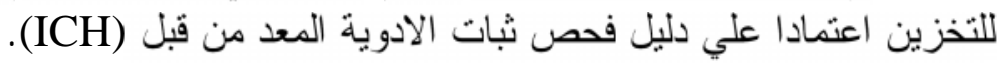

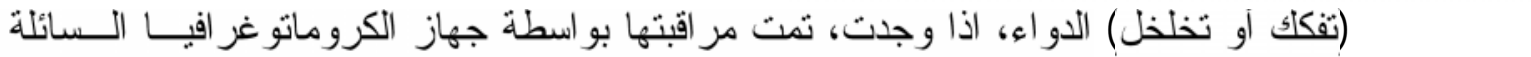

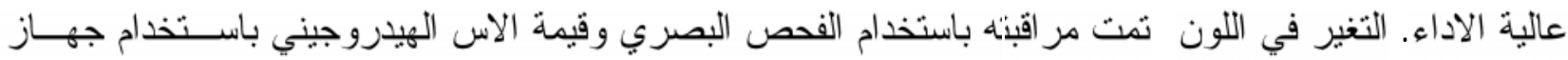

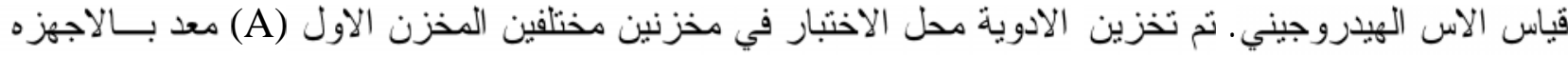

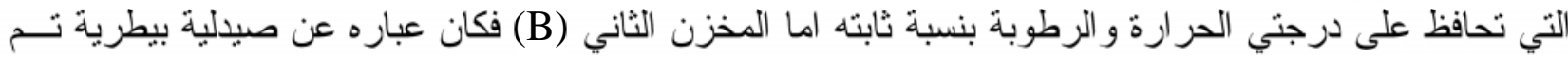

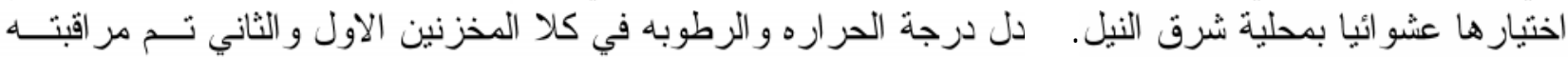

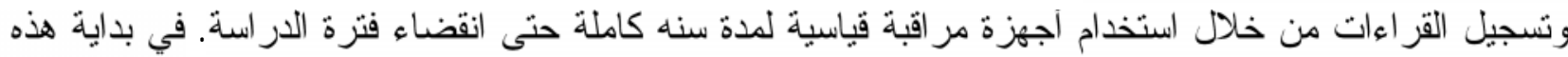

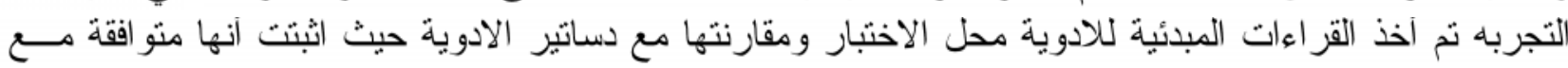
القر اءات الموصي بها.

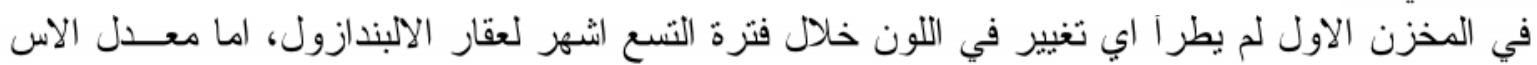

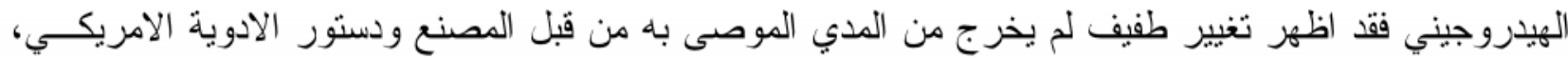

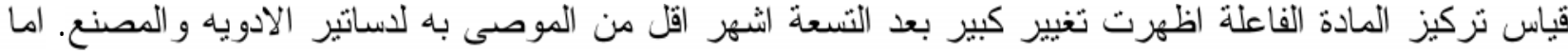

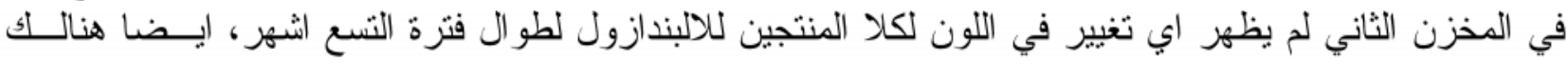

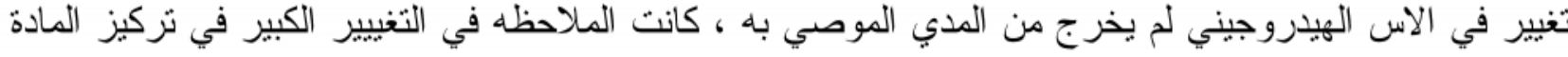

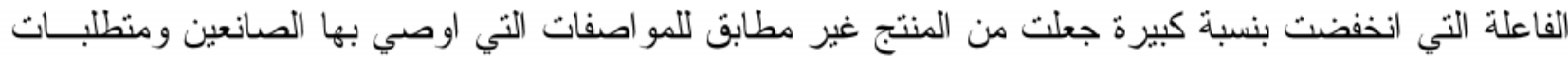
دسنور الادوية الامريكي. عقار الاوكسي تثز اسايكلين في المخزن الاول لم يظهر اي تغيير في اللون طو ال فترة الست اشهر للار اسه

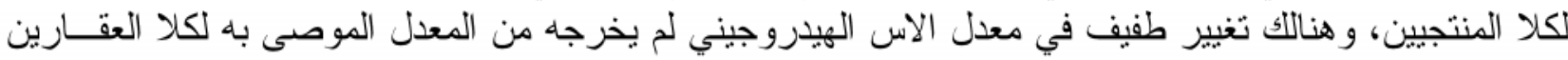

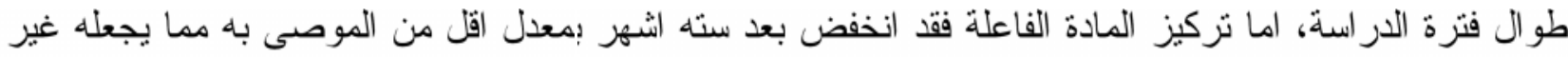

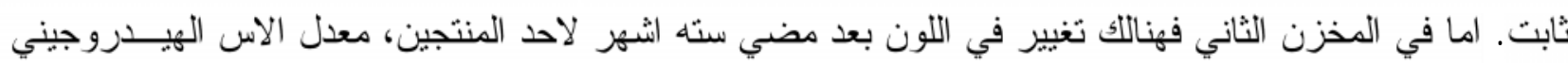

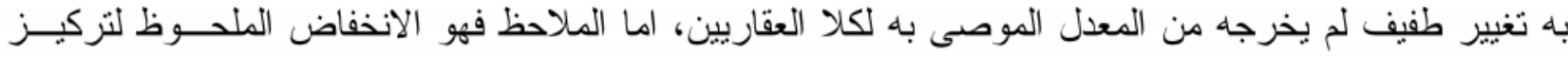

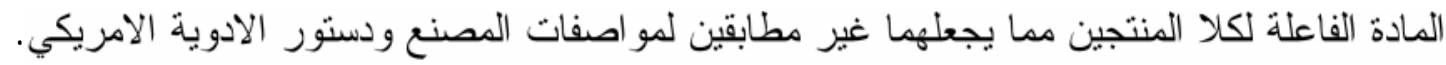

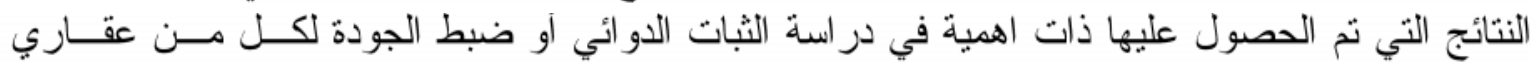

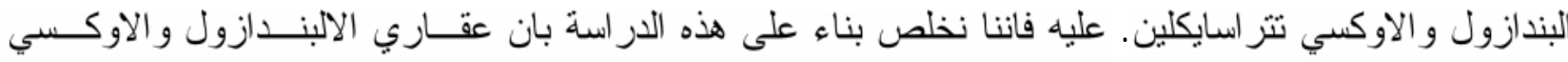

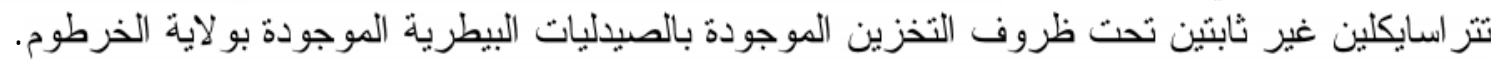

